\title{
THE TROTSKY PAPERS
}




\section{RUSSIAN SERIES}

ISSUED BY THE

INTER NATIONAAL INSTITUUT VOOR SOCIALE GESCHIEDENIS

A MSTERDAM

DIRECTOR: PROF. DR. FR. DE JONG, EDZ.

THE TROTSKY PAPERS

1917-1922

1971

MOUTON

THE HAGUE - PARIS 


\section{THE \\ TROTSKY PAPERS \\ 1917-1922}

edited and annotated by

JAN M. MEIJER

II

1920-1922

1971

MOUTON

THE HAGUE - PARIS 
The Editing of this Volume has been made possible by the financial support of The Netherlands' Organisation for the Advancement of Pure Research (Z.W.O.).

(C) COPYRIGHT RESERVED

PRINTED IN THE NETHERLANDS 